\title{
Effects of different cooking methods on folate retention in selected mushrooms
}

\author{
Su-Jin Park ${ }^{1}$, Sun-Hye Park ${ }^{1}$, Heajung Chung ${ }^{2}$, Junsoo Lee ${ }^{3}$, \\ Taisun Hyun ${ }^{4}$, Jiyeon Chun ${ }^{1 *}$ \\ ${ }^{1}$ Department of Food Science and Technology, Sunchon National University, Suncheon 57922, Korea \\ ${ }^{2}$ Department of Korean Cuisine, Jeonju University, Jeonju 55069, Korea \\ ${ }^{3}$ Department of Food Science and Biotechnologe, Chungbuk National University, Cheongju 28644, Korea \\ ${ }^{4}$ Department of Food and Nutrition, Chungbuk National University, Cheongju 28644, Korea
}

\section{다양한 조리법에 따른 버섯류의 엽산 리텐션}

\author{
박수진 ${ }^{1} \cdot$ 박선혜 $^{1} \cdot$ 정혜정 $^{2} \cdot$ 이준수 $^{3} \cdot$ 현태선 $^{4} \cdot$ 천지연 $^{1 *}$ \\ ${ }^{1}$ 순천대학교 식품공학과, ${ }^{2}$ 전주대학교 한식조리학과, ${ }^{3}$ 충북대학교 식품생명공학과, ${ }^{4}$ 충북대학교 식품영양학과
}

Abstract

This study was performed to investigate the effects of different cooking methods (boiling, roasting, stir-frying, and deep-frying) on folate retention in 6 kinds of mushrooms (Beech-, button-, Juda's ear-, oak-, oyster-, and winter-mushrooms) frequently consumed in Korea. In order to assure reliability of analytical data, trienzyme extraction- $L$ casei method was verified and analytical quality control was also evaluated. Folate contents of mushrooms varied by 6.04-64.82 $\mathrm{g} / 100 \mathrm{~g}$ depending on the type of mushrooms. and were significantly affected by cooking methods. Depending on cooking methods, folate contents of mushrooms decreased by $22-48 \%, 2-31 \%$, and $17-56 \%$ for Juda's ear-, oak- and oyster-mushrooms, respectively, while 17-90\% of folate was increased in Beech mushroom. Overall, the largest weight loss was found in boiled mushrooms, but the lowest one in deep-fried samples. True folate retention rates considering processing factor were less than $\mathbf{1 0 0} \%$ for all cooked mushrooms except for Beech samples. Overall, folate loss was the largest by boiling with water but the smallest by deep-frying. Both accuracy and precision of trienzyme extraction- $L$-casei method were excellent based on a recovery close to $100 \%$ and coefficient variations less than 3\%. Quality control chart of folate analysis $(n=26)$ obtained during the entire study and an international proficiency test $(\mathrm{z}-\mathrm{score}=-\mathbf{0 . 5})$ showed that trienzyme extraction- $L$ casei method is reliable enough for production of national folate database.

Key words : folate, mushroom, cooking method, retention, method validation

\section{서 론}

식품의 영양정보는 식품을 선택하는데 있어 직접적인 영향을 미치며 영양정보를 확인하는 사람은 그렇지 않은

*Corresponding author. E-mail : cjyfall@sunchon.ac.kr Phone : 82-61-750-3258, Fax : 82-61-750-3208

Received 28 November 2017; Revised 30 November 2017; Accepted 12 December 2017.

Copyright (C) The Korean Society of Food Preservation. All rights reserved.
사람에 비해 건강이 좋아 대사증후군의 유병율이 낮고, 과 채류의 섭취가 늘어 식사의 질이 높아진다고 조사되었다 $(1,2)$. 이러한 식품에 대한 관심은 곧 건강과 직결되고 있는 바, 장수백세를 위해 매일 섭취하는 식단을 통한 영양소의 섭취 수준에 대한 관심과 함께 식품 중의 영양성분에 대한 신뢰도 높은 데이터베이스에 대한 요구도 높아지고 있다. 국내에서는 농촌진흥청, 식약처, 한국영양학회, 한국식품 연구원 등 다양한 기관 및 단체에서 국내 식품자원의 영양 성분 데이터의 생산 및 검증을 통한 데이터베이스를 구축해 오고 있으나 여전히 많은 식품 자원에 대한 영양성분의 
데이터베이스가 부족하여 상당 부분의 식품은 미국이나 일본에서 구축한 국가식품성분 데이터베이스를 활용하고 있는 실정으로 국가표준영양성분 데이터베이스로 활용할 수 있는 신뢰도 높은 국내 자원의 영양성분 분석 데이터의 생산 및 검증이 요구되고 있다.

엽산(folate)은 수용성 비타민 B 그룹의 하나로 체내에서 비타민 활성을 보이는 pteroic acid의 유도체들로 인체 내에 서 DNA 합성과 아미노산 대사에 필수적인 역할을 한다 $(3,4)$. 특히, 임산부의 경우 엽산 결핍에 의해 태아의 신경관 결함(neural tube defect)을 초래하게 되어 기형아 출산율이 높아지기 때문에, 미국에서는 엽산 강화를 의무화하여 엽 산을 강화한 fortified flour를 국민 식단으로 이용하게 하는 영양정책을 실시하고 있으며, 유럽 또한 엽산 강화를 권장 하는 정책을 운영하고 있다. 우리나라의 경우에서도 임산 부, 수유부 및 성인 여성의 엽산 섭취량이 높지 않아 엽산이 풍부한 식품이나 보충제를 이용한 엽산의 보충이 필요한 것으로 보고되고 있다 $(3,5,6)$.

버섯류는 지방 함량이 낮고 난소화성 탄수화물로 구성되 어 칼로리가 낮으며 비타민과 무기질이 풍부할 뿐 아니라, 독특한 향, 맛, 조직감을 보유하고 있기 때문에 기호 식품으 로서 가치가 크다(7,8). 또한, 식이섬유 함량이 높고 lentinan, inotodiol, bolegrevilol 등과 같은 다양한 생리활성 물질들이 존재하고 있어 항산화, 항암, 항염증 등의 기능성을 나타내 는 것으로 보고되고 있어(9-12) 식단에서의 활용 빈도와 섭취량이 꾸준히 증가하고 있는 추세이다. 버섯은 생으로 섭취하기보다는 주로 굽기, 볶기, 튀기기 등 다양한 조리 후 섭취하게 되는데 이러한 식품의 조리 및 가공과정은 영양성분이나 생리활성 물질을 매트릭스로부터 분리시켜 섭취 시 생체이용도를 향상시키는 긍정적 역할을 할 뿐만 아니라(13), 유용성 물질들의 화학적 분해 및 외부로의 용출 로 인한 손실을 가져오는 부정적인 영향을 미치기도 한다 (14-16). 현재, 버섯을 이용한 스폰지 케이크, 국수, 쿠키
등 다양한 기능성 개선을 통한 제품 개발에 관한 연구들이 (17-19) 보고되고 있으나 조리법에 따른 버섯의 영양성분 잔존율에 관한 연구는 보고된 바가 없다.

본 연구는 국가식품 영양성분 데이터베이스로 활용하기 위한 시료의 대표성과 데이터의 신뢰도 확보를 위해 6 종의 버섯을 4 가지 표준조리법으로 조리하였으며 엽산 분석에

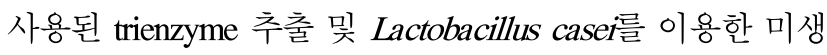
물학적 분석법의 유효성 검증(method validation) 및 내외부 적 분석 품질관리(quality control, QC)를 수행하였다. 국가 식품 영양성분 데이터베이스 구축 사업의 일환으로 국내에 서 다소비 되고 있는 버섯 6 종에 대하여 총 4 가지 조리법에 따른 엽산 함량의 잔존율 변화를 조사하여 조리된 버섯에 대한 엽산 데이터베이스 구축 자료로 활용하고자 하였다.

\section{재료 및 방법}

시 약

Folic acid 표준품, protease, $a$-amylase는 Sigma Aldrich (St. Louis, MO, USA)에서 구입하였으며, folate conjugase (chicken pancreas)는 Pel-Freeze Biologicals(Rogers, AR, USA)에서 구입하였다. 엽산 분석에 사용된 Lactobacillus casei subsp. rhamnosus(ATCC 7469)는 ATCC(American Type Culture Collection, Manassas, VA, USA)에서 구입하였 으며 배양 배지로 사용된 folic acid casei medium, Lactobacili agar AOAC, Lactobacili broth AOAC는 Difco 사(Beckton-Dickinson, Sparks, MD, USA)에서 구입하여 냉 장보관하며 사용하였다. 증류수는 water purification system(Aqua MaxTM-Ultra, Young Lin Instrument Co., Anyang, Korea)으로 정제하여 사용하였으며, 기타 사용된 시약은 GR 등급 이상을 사용하였다.

Table 1. Cooking conditions of boiling, roasting, stir-frying, and deep-frying

\begin{tabular}{lccccccc}
\hline \multirow{2}{*}{ Samples } & \multicolumn{2}{c}{ Boiling } & \multicolumn{2}{c}{ Roasting } & \multicolumn{2}{c}{ Stir-Frying } & \multicolumn{2}{c}{ Deep-frying } \\
\cline { 2 - 8 } & $\begin{array}{c}\left.\mathrm{WV}^{1}\right) \\
(\mathrm{mL})\end{array}$ & $\begin{array}{c}\mathrm{CT}^{2} \\
(\mathrm{~min})\end{array}$ & $\begin{array}{c}\mathrm{CT} \\
(\mathrm{min})\end{array}$ & $\begin{array}{c}\text { OV } \\
(\mathrm{mL})\end{array}$ & $\begin{array}{c}\mathrm{CT} \\
(\mathrm{min})\end{array}$ & $\begin{array}{c}\text { OV } \\
(\mathrm{mL})\end{array}$ & $\begin{array}{c}\mathrm{CT} \\
(\mathrm{min})\end{array}$ \\
\hline Beech mushroom (Lyophyllum ulmarium) & 3,000 & 3.0 & 8.0 & 60 & 6.0 & 3,000 & 1.5 \\
Button mushroom (Agaricus bispor & 3,000 & 2.5 & 3.0 & 100 & 4.0 & 3,000 & 2.0 \\
Ear mushroom (Auricularia auricula) & 3,000 & 3.0 & 4.5 & 60 & 3.5 & 3,000 & 0.5 \\
Oak mushroom (Lentinula edodes) & 3,000 & 1.5 & 3.0 & 100 & 3.0 & 3,000 & 1.0 \\
Oyster mushroom (Pleurotus ostreatus) & 3,000 & 2.0 & 2.5 & 100 & 2.5 & 3,000 & 1.0 \\
Winter mushroom (Flammulina velutipes) & 3,000 & 1.0 & 3.0 & 60 & 2.5 & 3,000 & 2.0 \\
\hline
\end{tabular}

${ }^{1} \mathrm{WV}$, water volume.

${ }^{2)} \mathrm{CT}$, cooking time.

${ }^{3} \mathrm{OV}$, oil volume. 
시료 준비

버섯 시료는 전라북도 전주 농수산물시장에서 구매한 후 구매 즉시 비가식 부위를 제거 및 손질하여 식약처의 국가식품 영양성분 데이터베이스 구축을 위한 4가지 표준 조리법을 이용하여 조리되었다. 사용된 조리 기구는 인덕 션(DaeRyung, Seoul, Korea)과 전기 튀김기(DK-201, Delki, Goyang, Korea)를 사용하였으며 조리 시간 및 조리수와 조리유의 사용량은 Table 1과 같다. 먼저, 양송이버섯 (button mushroom, Agaricus bisporus)과 표고버섯(oak mushroom, Lentinula edodes)은 $1 \mathrm{~cm}$ 두께로, 느타리버섯 (oyster mushroom, Pleurotus ostreatus)은 $0.5 \mathrm{~cm}$ 두께로, 목이버섯(Juda's ear mushroom, Auricularia auricula)은 사 방 $4 \mathrm{~cm}$ 길이로, 백만송이버섯(Beech mushroom, Lyophyllum ulmarium)과 팽이버섯(winter mushroom, Flammulina velutipes)은 손으로 찢어 손질하였다. 시료의 조리방법은 조리전문가 및 국가영양성분 데이터베이스를 생산하고 있 는 식품의약품안전처와 협의하여 총 4 가지 표준조리법으 로 조리하였다. 원재료는 증류수로 세척하였으며 삶기는 증류수를 넣고 끓는 상태에서 1-3분 동안 삶았다. 굽기는 인덕션 4단계의 열에서 2-4.5분간 조리했다. 볶기는 인덕션 4단계의 열에서 2.5-6분 동안 조리했다. 튀기기는 식용유를 $180^{\circ} \mathrm{C}$ 로 가열 후 0.5-2분간 조리한 다음 키친 타올 3겹으로 3 번 문질러 기름기를 제거하였다. 모든 시료는 소분하여 3회 이상 반복하여 조리한 후 시료 균질기(HGBSS, Waring, Torrington, CT, USA)로 균질한 다음 소분하여 $-70^{\circ} \mathrm{C}$ 에 보관 하며 분석에 사용하였다.

\section{엽산 추출 (tri-enzyme extraction)}

시료 중의 엽산 추출은 Chun 등(20)의 방법에 따라 protease, a-amylase, folate conjugase(chicken pancreas)를 사 용하여 가수분해하는 trienzyme 추출법을 사용하였다. 먼 저, 냉동 보관된 균질화된 시료를 실온에서 해동 시킨 후 $100 \mathrm{~mL}$ 광구 삼각플라스크에 $1 \mathrm{~g}$ 씩 칭 량하였다. 튀기기, 볶기 등의 조리법에 의해 지방 함량이 높아진(5\% 이상) 시료의 경우 hexane으로 지방을 제거한 다음 trienzyme으 로 추출하였다. 시료를 칭량한 삼각플라스크에 sodium phosphate buffer(pH 7.8) $20 \mathrm{~mL}$ 과 증류수 $30 \mathrm{~mL}$ 을 차례로 가한 후 $100^{\circ} \mathrm{C}$ 항온수조(WB-20M, Jeio Tech, Daejeon, Korea)에서 15 분간 열탕 처리하였다. 시료 플라스크를 실 온으로 식힌 후 protease $(2 \mathrm{mg} / \mathrm{mL}) 1 \mathrm{~mL}$ 과 sodium phosphate buffer(pH 7.8) $10 \mathrm{~mL}$ 을 가하여 $37^{\circ} \mathrm{C}$ shaking incubator에서 3 시간 동안 반응시켰다. 다음으로 $100^{\circ} \mathrm{C}$ 에서 10 분간 처리 하여 protease를 불활성화 시킨 후 실온으로 냉각하여 $a$ -amylase $(20 \mathrm{mg} / \mathrm{mL}) 1 \mathrm{~mL}$ 과 toluene $0.5 \mathrm{~mL}$ 을 가한 다음 $37^{\circ} \mathrm{C}$ shaking incubator에서 2시간 동안 처리하였다. 마지막 으로 folate conjugase solution $(5 \mathrm{mg} / \mathrm{mL}$ in assay buffer, $\mathrm{pH}$ 7.8) $4 \mathrm{~mL}$ 을 가한 후 $37^{\circ} \mathrm{C}$ shaking incubator에서 최대 16시
간 반응시킨 다음 5 분간 열탕 처리하여 효소를 불활성화 시켰다. 시료 반응액의 $\mathrm{pH}$ 는 $\mathrm{HCl}$ 용액을 이용하여 4.5 로 조정한 다음 $100 \mathrm{~mL}$ 로 정용하고 추출용액을 잘 혼합한 다음 여과지(Whatman No.1, GE Healthcare, Amersham, $\mathrm{UK})$ 로 여과하여 L. casei assay용 추출액으로 사용하였다. 공시험(blank)은 효소 blank로써 시료 없이 모든 추출법을 그대로 진행하였으며 시료 추출과 공시험을 함께 진행하였 다.

\section{엽산 분석 ( $L$ casei 법)}

시료 추출액의 엽산 정량은 L. casei가 엽산의 농도에 따라 성장하는 생육도를 microplate reader를 이용하여 측정 하였다. 고체 배지에 배양된 L. caser는 분석 당일 depletion media(folic acid casei medium:Lactobacilli broth=1:1, v/v)에 접종한 후 $37^{\circ} \mathrm{C}$ 에서 약 6시간 배양하였다. 엽산의 microbiological assay에 사용된 분석배지는 $10 \mathrm{~mL}$ 당 $L$. casei $50 \mu \mathrm{L}$, ascorbic $\operatorname{acid}(0.1 \mathrm{~g} / \mathrm{mL}) 100 \mu \mathrm{L}$ 를 가하여 제조하 였다. 이후 시료 추출액 $(150 \mu \mathrm{L})$ 을 96-well plate에 넣고 단계 희석한 다음 시료 추출액이 있는 각각의 well에 분석배지 $150 \mu \mathrm{L}$ 씩을 가한 후 $37^{\circ} \mathrm{C}$ 에서 $18-20$ 시간 동안 배양하였다. Microplate reader(Biotek Instruments, Winooski, VT, USA) 를 이용하여 흡광도 $595 \mathrm{~nm}$ 에서 탁도를 측정하였다. 추출 액의 엽산 함량은 엽산에 대한 L. casei 성장도를 탁도로 측정하고 엽산 표준용액에 대한 미생물 성장 반응곡선(검 량선)과 비교하여 계산하였다. 검량선은 Biotek사 microplate reader 기기의 Gen5 데이터 분석 소프트웨어(version 2.04) 를 사용하였으며 계산된 엽산 함량은 $\mu \mathrm{g} / 100 \mathrm{~g}$ 으로 나타내 었다. 분석품질관리와 효소 공시험(blank)도 같은 방법으로 시료와 함께 분석하였다.

\section{분석법 검증 (method validation)}

분석법 검증은 $\mathrm{AOAC}$ 가이드 라인(21)에 따라 단일 실험 실 분석법 수행특성을 분석하여 평가하였다. 분석법의 정 확성은 표준참고물질(standard reference material, SRM) SRM 1849a(infant/adult nutritional formula)를 NIST(National Institute of Standards and Technology, Gaithersburg, MD, USA)로부터 구입하였으며, NIST에서 제시한 인증값과 분 석으로 얻어진 측정값을 비교하여 정확성을 계산하였다. 정밀성은 품질관리(Quality Control, QC) 시료(commercial folate fortified flour)를 추출부터 분석까지 하루에 독립적으 로 5회 분석하여 반복성(repeatability, inter-day precision)을 계산하였으며, 5 일간 하루에 한번씩 3 반복으로 분석한 결 과를 재현성(reproducibility, intra-day precision)으로 계산 및 검증하였다.

\section{분석품질관리(analytical quality control)}

엽산 분석의 품질관리는 단일 실험실 분석 품질관리 가 
이드라인에 따라 수행하였다(21). 모든 시료의 엽산 함량 분석 시 $\mathrm{QC}$ 시료를 함께 분석하여 엽산 함량을 품질관리도 (QC chart)에 작성하였다. $\mathrm{QC}$ chart의 초기 기준선은 상대표 준편차가 $5 \%$ 이내인 최소 10 개의 데이터를 사용하여 설정 하였으며, 관리 상-하한선(upper and lower control line, $\mathrm{UCL}, \mathrm{LCL}$ )과 조치 상-하한선(upper and lower action line, $\mathrm{UAL}, \mathrm{LAL})$ 은 다음과 같이 설정하였다. 연구가 진행된 전 기간 동안의 엽산 분석에 대한 분석품질을 관리 및 조치하 였다.

UCL, LCL $(\mu \mathrm{g} / 100 \mathrm{~g})=$ mean of folate content in QC sample $\pm 2 \times$ SD

UAL, LAL $(\mu \mathrm{g} / 100 \mathrm{~g})=$ mean of folate content in $\mathrm{QC}$ sample $\pm 3 \times$ SD

UCL, LCL : upper and lower control line

UAL, LAL :upper and lower action line

SD : standard deviation

외부적인 분석품질관리를 위하여 영국 환경식품농림부 (Department for Environment Food and Rural Affairs, DEFRA)에서 주관하는 국제정도관리 분석능력시험 프로 그램인 Food Analysis Performance Assessment Scheme (FAPAS) Proficiency Test(PT) 2196에 참가하여 미생물법으 로 수행된 엽산 분석법 수행의 숙련도를 평가하였다. FAPAS PT 시험을 위한 시료는 breakfast cereal이었으며 배송 받은 직후 실험 전까지 $-70^{\circ} \mathrm{C}$ 에 보관하며 분석에 사용 하였다. 분석 숙련도 시험에 대한 평가는 전 세계적으로 FAPAS PT 2196에 참가한 실험실의 엽산 분석 결과를 토대 로 산출한 z-score를 비교 평가하였다.

가공계수(processing factor) 및 잔존율(true retention)

가공계수(processing factor)와 잔존율(true retention)은 $\mathrm{Kim}$ 등(22)에 따라 계산하였다. 가공계수는 공정과정 중에 생기는 시료의 중량 또는 부피의 변화를 계산하는 지표로 시료의 조리 전과 후의 중량을 측정하여 다음과 같이 계산 하였다.

Processing factor $(\%)=\mathrm{WV} / \mathrm{WVr} \times 100$

WVc : weight of cooked food

WVr : weight of raw food

시료의 엽산 잔존율은 조리 전과 후의 중량을 고려하여 다음과 같이 계산하였다.

True retention $(\%)=100 \times(\mathrm{Nc} \times \mathrm{Gc}) /(\mathrm{Nr} \times \mathrm{Gr})$

Nc:nutrient content/g of cooked food

Gc : $g$ of cooked food
$\mathrm{Nr}$ : nutrient content/g of raw food

Gr : $g$ of raw food

\section{통계 분석}

각 실험은 모두 3 반복 실험으로 진행되었으며, 결과의 통계 처리는 SPSS(Statistical Package for the Social Science, Chicago, IL, USA) program version 24를 이용하여 분석하였 다. 조사된 항목에 대해 평균과 표준편차를 구하였으며, 각 항목의 평균값의 차이는 유의수준 $\mathrm{p}<0.05$ 에서 일원 분산 분석법(one-way ANOVA test)을 이용하여 검증하였고, 시 료 간의 유의성은 Duncan's multiple range test로 검정하여 분석 평가하였다.

\section{결과 및 고찰}

\section{엽산 분석법 검증}

Trienzyme 추출 및 $L$ casee를 이용한 엽산 분석의 정확성 검증을 위해 표준참고물질을 분석한 결과는 Table 2 와 같 다. Trienzyme extraction-L. casei 분석법으로 분석한 SRM $1849 \mathrm{a}$ 의 엽산 함량은 $230.1 \pm 2.8 \mu \mathrm{g} / 100 \mathrm{~g}$ 였으며 이는 SRM $1849 \mathrm{a}$ 의 인증값 $(229.3 \pm 6.2 \mu \mathrm{g} / 100 \mathrm{~g})$ 과 비교 시 회수율 $100.4 \%$ 를 보였다. AOAC 가이드라인(21)에서 분석성분의 농도가 $1 \mathrm{\mu g} / \mathrm{g}$ 수준일 때 수용할 수 있는 회수율은 75-120\% 로 넓은 범위를 수용하고 있으나 본 연구에서 trienzyme 추출 및 $L$ casei를 이용한 분석으로 얻은 회수율은 약 $100 \%$ 로 우수한 정확성을 보여준다 하겠다. 분석품질관리 시료 로 사용되는 상업용 분유 시료를 반복 분석하여 측정한 정밀성 결과는 Table 3 과 같다. 미생물학적 분석법을 이용 하여 측정한 반복성과 재현성의 변동계수(coefficient of variation, $\mathrm{CV}$ )는 각각 2.17 과 $1.47 \%$ 로 약 $3 \%$ 이하의 낮은 값이었다. 이는 $\mathrm{AOAC}$ 가이드라인(21)에서 수용 가능한 분석법의 정밀성을 얻기 위해서는 분석성분 농도 $1 \mu \mathrm{g} / \mathrm{g}$ 일 때 반복성은 $8 \%$, 재현성은 $16 \%$ 의 $\mathrm{RSD}$ 를 요구하고 있는 것과 비교해 볼 때 우수한 정밀성을 갖고 있음을 보여준다. 일반적으로 미생물학적 분석법은 분석 균주의 상태에 따라 분석치에 영향을 줄 수 있기 때문에 기기 분석법에 비하여 정밀성이 부족할 수 있으나 본 연구에서 얻어진 반복성과 재현성은 모두 매우 낮은 값을 나타내어 분석법의 정밀성이

Table 2. Accuracy of folate analysis by trienzyme extraction- $L$. casei

\begin{tabular}{lccc}
\hline \multirow{2}{*}{ Sample (CRM) } & \multicolumn{3}{c}{ Folate content $(\mu \mathrm{g} / 100 \mathrm{~g})$} \\
\cline { 2 - 4 } & Certified value $^{2)}$ & Analytical value $^{3)}$ & Recovery (\%) \\
\hline SRM 1849a & $229.3 \pm 6.2$ & $230.3 \pm 2.8$ & 100.4 \\
\hline${ }^{1)} \mathrm{CRM}$, certified reference materials; SRM & $1849 \mathrm{a}=$ =Infant/adult nutritional formula. \\
${ }^{25}$ The certified value of folate by NIST (National Institute of Standards and Technology). \\
${ }^{3)}$ The analytical value obtained by microbiological assay.
\end{tabular}


Table 3. Precision of folate analysis by trienzyme extraction- $L$. casei

\begin{tabular}{|c|c|c|}
\hline \multirow{2}{*}{ Parameters ${ }^{1)}$} & \multicolumn{2}{|c|}{ Folate content $(\mu \mathrm{g} / 100 \mathrm{~g})$} \\
\hline & Repeatability ${ }^{2)}$ & Reproducibility ${ }^{3)}$ \\
\hline Mean \pm SD & $180.39 \pm 3.91$ & $183.64 \pm 2.69$ \\
\hline $\mathrm{CV}(\%)$ & 2.17 & 1.47 \\
\hline $\begin{array}{l}{ }^{1)} \mathrm{n}=5 \text { in triplicates; } \\
\text { 2) Repeatability refers } \\
\text { of folate in a Q } \\
\text { 3) Reproducibility r } \\
\text { each) of folate is } \\
\text { days. }\end{array}$ & $\begin{array}{l}\text { deviation; CV } \\
\text { ts of five indep } \\
\text { erformed in a } \\
\text { esults of five } \\
\text { tple performed }\end{array}$ & $\begin{array}{l}\text { variation })=100 \times(\mathrm{SD} / \\
\text { ninations (triplicates } \\
\text { determinations (trip } \\
\text { for five different }\end{array}$ \\
\hline
\end{tabular}

우수하다고 판단된다.

Puwastien 등(23)은 세계 여러 실험실에 세 가지의 시료 (soybean, fish powder, breakfast cereal)의 엽산 분석을 의뢰 하여 분석값을 취합한 결과 참여한 총 26 개 실험실의 엽산 분석값에 큰 차이가 있었으며 이러한 차이는 추출방법이나 검출 및 정량법의 차이에 의하여 발생될 수 있기 때문에 공동연구를 진행하는 경우 분석법을 통일하거나 표준참고 물질을 활용하는 것이 분석 오차를 줄일 수 있다는 방법이 라고 보고하였다. 본 연구에서 생산되는 분석값은 다른 기 관들의 실험실에서 생산되는 데이터와 함께 식약처가 생산 하는 국가영양성분 데이터베이스에 이용되기 때문에 표준 참고물질을 이용하여 분석법을 비교 검증하는 것은 각 실험 실마다 생산되는 분석 데이터를 타 기관과 상호 교환 및 비교를 가능하게 하는데 필요하다 사료된다.

최근, WHO global action 2013-2020은 지역적, 국가적 수준의 영양관리시스템을 국제적 수준으로 관리하여 비전 염병(non-communicable disease)을 예방하고 관리하겠다는 계획을 발표하고 2025년까지 성취할 다양한 목표를 설정하
고 있으며 이러한 세계적 영양관리를 위해서는 식품영양데 이터베이스의 신뢰도 높은 구축과 함께 표준화가 무엇보다 중요하다고 발표하였다(24). 이는 현재 전 세계적으로 국가 적 차원에서 구축되고 있는 식품영양성분 데이터베이스를 $\mathrm{WHO}$ 를 비롯하여 건강영양정책과 관련된 여러 국제기구 및 협회들과 상호 교류 및 소통을 통하여 지금까지 국가적 차원에서 관리해온 영양 정책을 국제적 차원에서 유기적으 로 협조하여 인류의 건강을 개선하고자 하는 운동으로, 이 를 위해서는 각국에서 생산하고 있는 국가영양성분 데이터 베이스를 국제적으로 소통할 수 있도록 표준화하고 비교 가능한 데이터로 생산하는 것이 필요하며 이러한 분석법의 통일, 분석법 검증 데이터, 분석품질관리, 시료에 대한 정확 한 정보 제공 등을 포함한다(25).

\section{분석품질관리}

실험실 내부적으로 관리되는 분석품질은 분석 매개 변수 의 변화, 즉, 환경 요인, 기기 및 기기부속물, 실험 중 사용된 물질, 분석자 등에 대한 실험 반응의 정도를 확인하기 위해 실시되는데 미생물학적 분석법과 같이 균주의 성장속도에 따른 반응을 정량화하는 분석법에서는 시료를 분석할 때마 다 분석품질관리를 수행하는 것이 데이터의 신뢰도 확보에 필수적이다. 본 연구에서는 품질관리시료(상업용 밀가루) 를 시료 분석과 매번 함께 분석하고 set-up된 품질관리도표 (QC chart)를 이용하여 L. casei를 이용한 엽산 분석의 품질 을 모니터링 하였다(Fig. 1), QC chart의 set-up은 품질관리 시료를 10 회 이상 분석하여 표준편차가 $5 \%$ 이하인 10 개 분석값의 평균값 $(180.39 \mu \mathrm{g} / 100 \mathrm{~g})$ 을 기본으로 설정하여 관리선 172.58-188.20 $\mathrm{\mu g} / 100 \mathrm{~g}$ 범위와 조치선 168.67$192.11 \mathrm{\mu g} / 100 \mathrm{~g}$ 범위 안에서 분석값을 관리하였다. 시료와

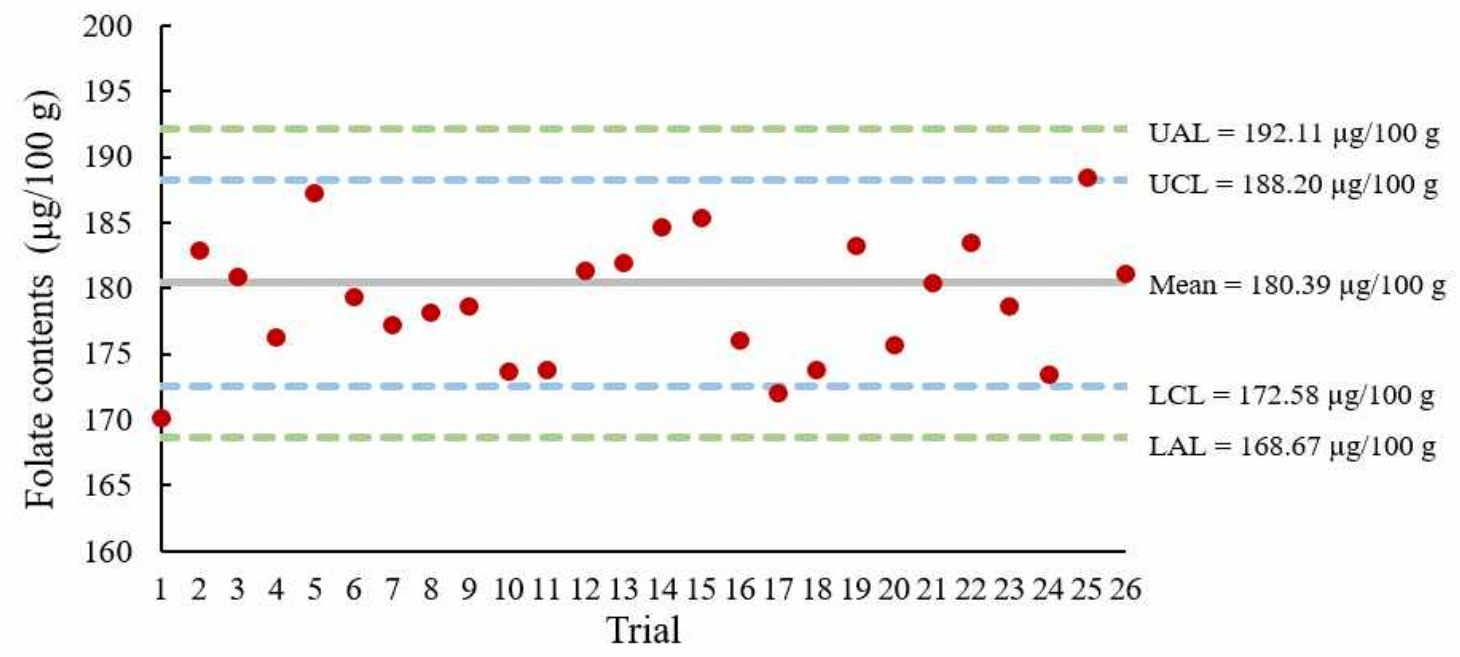

Fig. 1. Quality control chart of trienzyme extraction- $L$. casei assay for folate in commercial flour.

UCL and LCL (upper and lower control lines, respectively)=mean $\pm 2 \times \mathrm{SD}$; UAL and LAL (upper and lower action lines, respectively)=mean $\pm 3 \times \mathrm{SD}$. Each trial was the mean of duplicates analysis performed with every batch of test sample analysis. 
함께 분석한 품질관리시료의 분석치가 조치선 범위를 넘는 수준일 경우 분석 시스템을 재정비하고 함께 분석된 검체 시료의 분석값은 결과에서 삭제하였다. 시스템 점검 이후 품질관리시료의 값이 관리선 범위 내에 들어오게 되는 경우 다시 시료의 분석을 진행하였다. Fig 1 에서 보여주듯이 모 든 시료의 분석과 함께 진행된 품질관리시료의 분석값은 $\mathrm{QC}$ chart의 관리수준 범위(172.58-188.20 $\mu \mathrm{g} / 100 \mathrm{~g})$ 이내에 들어갔으며, 이는 시료가 분석된 모든 기간 동안 분석 품질 이 잘 관리되어 진행되었음을 나타내는 것으로 시료 분석 데이터의 신뢰도를 보여주는 것으로 판단된다.

한편, 외부적으로 분석품질을 인정받을 수 있는 국제 분 석 숙련도 시험(FAPAS PT 2196)에 trienzyme extraction-L casei 분석법으로 참여하여 시험 시료인 breakfast cereal을 분석한 결과, NIST기관에서 제시한 인증값 $151 \mu \mathrm{g} / 100 \mathrm{~g}$ 보다 다소 낮은 $139.927 \mu \mathrm{g} / 100 \mathrm{~g}$ 의 값을 얻었으며 이에 대한 z-score는 -0.5였다(Table 4). 한편, 같은 시험에 참여한 실험실에서 본 연구와 같은 미생물법을 포함하여 HPLC, ELISA, LC-MS/MS와 같은 기기 분석법을 이용하여 breakfast cereal을 분석한 결과는 Fig. 2와 같다. FAPAS PT-2196에 참여한 총 16 개 실험실의 엽산 분석 결과는 95.6-211 $\mathrm{\mu g} / 100 \mathrm{~g}$ 의 범위로 상당히 넓은 엽산 함량 범위를

Table 4. z-Score of trienzyme extraction- $L$. casei assay for breakfast cereal test sample in the FAPAS Proficiency Test 2196

\begin{tabular}{cccc}
\hline \multirow{2}{*}{ Test sample } & \multicolumn{2}{c}{ Folate content $(\mathrm{\mu g} / 100 \mathrm{~g})$} & \multirow{2}{*}{ z-Score } \\
\cline { 2 - 3 } & Certified value $^{1)}$ & Analytical value $^{2)}$ & \\
\hline Breakfast cereal & 151 & 139.927 & -0.5 \\
\hline
\end{tabular}

${ }^{1}$ The certified folate value of breakfast cereal was provided by NIST based on analytical results of 16 laboratories participated in the FAPAS (Food Analysis Performance Assessment Scheme) proficiency test 2196.

${ }^{2}$ The analytical value was obtained from trienzyme extraction- $L$ casei assay for folate of breakfast cereal.
나타내었다. 일반적으로 $\mathrm{z}$-score가 \pm 2 에 범위 안에 속할 때 분석 숙련도가 우수함을 나타내므로 Fig. 2에서 z-score 가 \pm 2 범위 이내에 속하는 14 개 실험실의 분석은 숙련도 높게 진행된 것으로 평가되나 이 범위를 벗어난 5 번과 14 번 실험실의 경우 국제적으로 상호 소통하기에는 미흡한 수준 의 분석이 진행된 것으로 판단된다. 한편, LC-MS/MS 분석 법을 이용한 1 번 실험실의 z-score는 +0.5 로 본 연구에서 사용한 미생물학적 분석법의 z-score(실험실 번호-29)와 동 일한 절대값을 보였다. 이는 trienzyme extraction- $L$ casei 분석법이 다른 기기 분석법과 함께 소통할 수 있는 정도의 대외적으로 우수한 분석 숙련성을 나타내는 분석법을 나타 내는 것으로 판단된다.

\section{조리법에 따른 버섯류의 엽산 함량}

표준조리법을 따라 버섯 6 종을 Table 1 과 같은 조건의 4가지 방법(삶기, 굽기, 볶기, 튀기기)으로 조리한 후 변화된 엽산 함량은 Table 5 와 같다. 생버섯 6 종의 엽산 함량은 6.04-64.82 $\mathrm{\mu g} / 100 \mathrm{~g}$ 으로 종류에 따라 넓은 범위를 보였으 며, 조리 후 이들의 엽산 함량의 차이에서도 시료의 종류와 조리법에 따라 다르게 나타났다. 목이, 표고, 및 느타리버섯 은 모든 조리법에서 원재료에 비하여 엽산 함량이 각각 약 22-48, 2-31, 17-56\%로 감소하였으며, 백만송이버섯은 모든 조리법에서 엽산 함량이 약 $17-90 \%$ 까지 증가하는 것 으로 나타났다. 반면, 팽이버섯의 경우 삶기에서는 원재료 대비 엽산 함량이 약 $34 \%$ 감소하였으나 튀기기에서는 약 $465 \%$ 증가하였고, 양송이버섯의 경우도 원재료 대비 엽산 함량이 삶기에서 약 $16 \%$ 감소하였으나 튀기기에서는 약 $24 \%$ 증가하는 것으로 나타났다. Park 등(26)은 표고버섯과 느타리버섯, 양송이버섯을 물에 끓이는 방법이 비타민 D2 함량에는 영향을 주지 않으나, 비타민 B2 함량은 $32-80 \%$ 의 감소 현상을 보인다고 보고하였다. 또한, $\mathrm{Kim}$ 등(27)은 세

FAPAS ${ }^{\circ}$ Report 2196

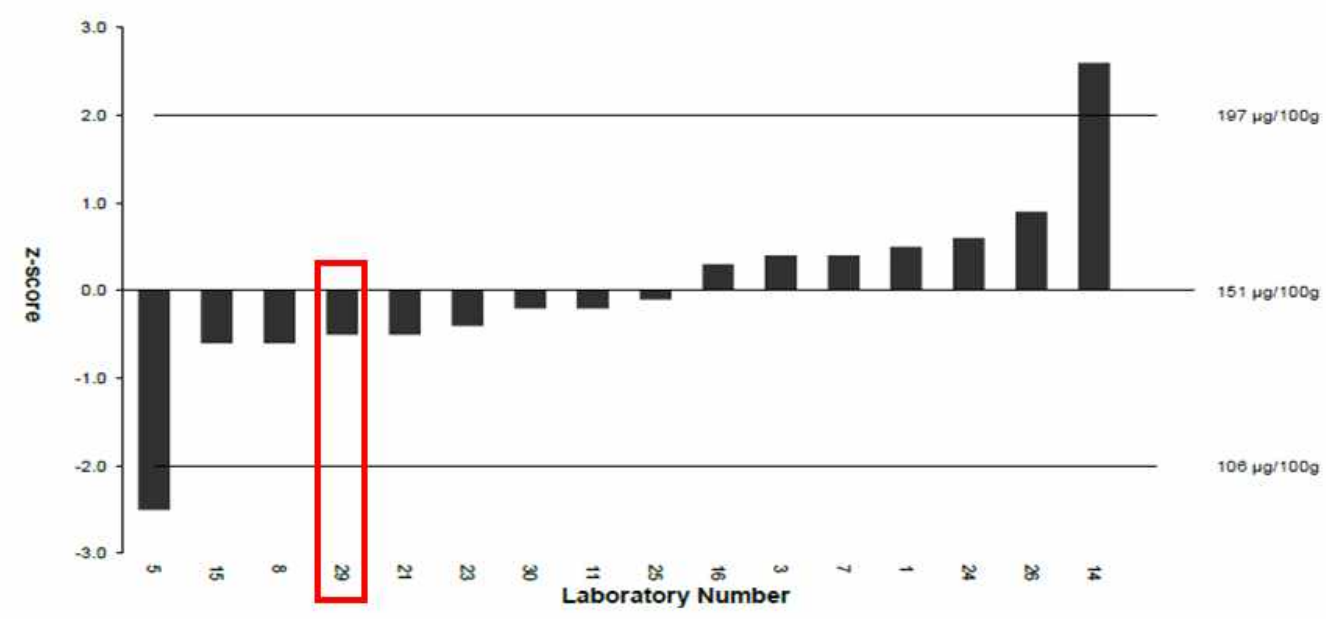

Fig. 2. FAPAS PT-2196 result and z-score for folate in breakfast cereal test material. 
Table 5. Folate contents in raw and cooked mushroom $(\mu \mathrm{g} / 100 \mathrm{~g} \text {, wet basis })^{1)}$

\begin{tabular}{|c|c|c|c|c|c|}
\hline Sample & $\operatorname{Raw}^{* *}$ & Boiled $^{* * *}$ & Roasted $^{\text {** }}$ & Stir-fried ${ }^{*}$ & Deep-fried $^{* * *}$ \\
\hline Beech mushroom $(L \text { ulmarium })^{* *}$ & $15.52 \pm 4.16^{\mathrm{dB}}$ & $18.08 \pm 2.67^{\mathrm{bcB}}$ & $24.72 \pm 1.31^{\mathrm{bA}}$ & $25.39 \pm 0.47^{\mathrm{abA}}$ & $29.46 \pm 0.64^{\mathrm{bcA}}$ \\
\hline Button mushroom ( $A$ bisporus $)$ & $20.09 \pm 6.75^{\mathrm{bcd}}$ & $16.88 \pm 6.19^{c}$ & $21.22 \pm 0.13^{\mathrm{b}}$ & $19.50 \pm 3.73^{\mathrm{ab}}$ & $24.87 \pm 5.94^{\mathrm{c}}$ \\
\hline Ear mushroom ( $A$ auricula $)$ & $6.04 \pm 0.20^{\mathrm{d}}$ & $3.17 \pm 1.48^{\mathrm{d}}$ & $4.39 \pm 2.1^{0 \mathrm{c}}$ & $4.32 \pm 1.89^{\mathrm{b}}$ & $4.72 \pm 1.53^{\mathrm{c}}$ \\
\hline Oak mushroom (L. edodes) & $28.60 \pm 9.30^{\mathrm{bc}}$ & $19.87 \pm 2.00^{\mathrm{bc}}$ & $23.37 \pm 1.27^{\mathrm{b}}$ & $26.12 \pm 0.37^{\mathrm{ab}}$ & $27.91 \pm 6.19^{c}$ \\
\hline Oyster mushroom ( $P$. ostreatus $)^{*}$ & $64.82 \pm 24.98^{\mathrm{aA}}$ & $28.28 \pm 2.59^{\mathrm{aB}}$ & $39.25 \pm 12.60^{\mathrm{aAB}}$ & $49.35 \pm 13.04^{\mathrm{aAB}}$ & $53.53 \pm 7.44^{\mathrm{bAB}}$ \\
\hline Winter mushroom $(F . \text { velutipes })^{* * *}$ & $38.72 \pm 5.56^{\mathrm{bB}}$ & $25.70 \pm 7.20^{\mathrm{abB}}$ & $37.56 \pm 10.82^{\mathrm{aB}}$ & $40.42 \pm 8.54^{a \mathrm{~B}}$ & $218.72 \pm 35.89^{\mathrm{aA}}$ \\
\hline
\end{tabular}

${ }^{1)}$ Mean \pm SD, Means with different capital letters in the same row and small letters in the same column are significantly different among groups at ${ }^{*} \mathrm{p}<0.05$, ${ }^{* *} \mathrm{p}<0.01,{ }^{* * *} \mathrm{p}<0.001$ level by Duncan's multiple range test.

발나물, 비름, 취나물을 30 초 데쳤을 때 각각 $11,48,26 \%$ 로 엽산 함량이 감소한다고 보고하였고, $\operatorname{Min}(28)$ 은 시금치를 끓는 물에 1 분 조리 시 엽산 함량이 $19.3 \%$ 감소하였으며, 조리시간이 길어짐에 따라 조리수로의 엽산 용출로 인하여 엽산 함량이 최대 $88.8 \%$ 까지 감소하였다고 보고하였다.

본 연구에서도 백만송이버섯을 제외한 모든 시료에서 조리수를 이용한 삶는 조리법이 다른 조리법에 비하여 엽산 함량이 낮게 나타났는데 이는 엽산이 비교적 열에는 안정하 지만 수용성인 특성으로 인하여 조리수가 사용되는 조리법 에서 용출로 인한 손실이 나타난 것이라 사료된다. 엽산 함량은 본 연구에서 적용된 4가지 조리법 중에서 튀기는 조리법이 가장 높은 함량을 유지하는 것으로 나타났다. $\operatorname{Kim}$ 등(29)에 따르면 여러 조리법으로 조리된 표고버섯, 느타리버섯, 양송이버섯의 관능적 특성을 10점 척도법으로 조사한 결과 튀기는 조리법이 색, 향, 맛, 조직감, 및 전체적 인 만족도에서 모두 유의적으로 가장 높게 평가되었다고 보고하였다. 이러한 연구 결과를 볼 때, 버섯류의 경우 관능 적으로도 우수하면서 수용성 비타민인 엽산의 손실을 막기 위해서는 튀기기와 같은 조리법이 바람직할 것이라 사료된 다.

\section{조리법에 따른 버섯류의 엽산 가공계수 및 잔존율}

버섯류의 조직은 대부분 수분으로 구성되어 있어 조리 방법에 따른 수분의 손실에 따라 영양성분 및 기능성 성분 들의 잔존율이 달라질 수 있다. 따라서 버섯류의 엽산 잔존 율 분석을 위해 조리법에 따라 변화되는 시료의 무게 변화 를 나타내는 가공계수(processing factor)를 고려하여 잔존 율을 평가하는 것이 필요하다. Table 6 은 6 종의 버섯을 4 가 지 조리법으로 조리한 전과 후의 무게 변화를 고려하여 계산한 중량가공계수를 나타낸다. 대부분 버섯의 중량은 4 가지 조리법에 의하여 감소함을 보였는데, 감소되는 양은 시료의 특성과 조리법에 따라 다르게 나타났으며, 삶기 $68.6-109.2 \%$, 굽기 $62.0-81.1 \%$, 볶기 $64.6-85.8 \%$, 튀기기 27.5-80.2\%로 감소되었다. 조리 방법 중 조리수를 이용하는 삶기에서는 버섯의 무게 감소가 상대적으로 적었으며 고온 에서 수분이 없이 조리하는 튀기기에서는 중량 손실이 상대
Table 6. Processing factor of cooked mushroom

\begin{tabular}{lrrrcc}
\hline \multirow{2}{*}{ Sample } & \multicolumn{5}{c}{ Processing factor ${ }^{1)}(\%)$} \\
\cline { 2 - 6 } & Raw & Boiled & Roasted & Stir-fried & Deep-fried \\
\hline Beech mushroom $(L$. ulmarium $)$ & 100.0 & 86.4 & 76.8 & 73.7 & 68.0 \\
Button mushroom $(A$ bisporus $)$ & 100.0 & 68.6 & 62.0 & 64.6 & 52.0 \\
Ear mushroom $(A$ auricula $)$ & 100.0 & 109.2 & 81.1 & 85.8 & 80.2 \\
Oak mushroom $(L$ edodes $)$ & 100.0 & 108.8 & 73.8 & 78.8 & 74.9 \\
Oyster mushroom $(P$. ostreatus $)$ & 100.0 & 80.7 & 73.9 & 78.3 & 54.5 \\
Winter mushroom $(F$. velutipes $)$ & 100.0 & 81.4 & 79.5 & 85.7 & 27.5 \\
\hline
\end{tabular}

${ }^{1)}$ Processing factor $(\%)=$ weights of cooked food/weights of raw food $\times 100$.

적으로 크게 나타났다.

이러한 가공 수율의 차이를 고려하여 조리된 버섯류에 남아있는 엽산의 잔존율을 계산한 결과는 Fig. 3 와 같다. 백만송이버섯을 제외한 버섯류에서 대부분 조리에 의하여 엽산 손실이 발생되어 원재료 $100 \%$ 보다 낮은 잔존율을 보이는 것으로 확인되었으며, 특히 전체적으로 삶는 조리 에서 엽산 잔존율 감소가 크고 튀기기에서는 비교적 엽산 잔존율이 높게 유지되는 것으로 나타났다. 이는 미국 버섯 류의 엽산 함량은 약 $28.9 \mathrm{\mu g} / 100 \mathrm{~g}$ 이하 수준이었고, 조리법 에 따라 감소한다고 보고한 Haytowitz(30)와 유사한 결과를 나타내었다. 한편, 느타리버섯의 경우 삶기는 약 $35.2 \%$ 로 엽산 잔존율이 가장 낮았고, 팽이버섯은 튀기기 $(155.2 \%)$ > 볶기 $(89.4 \%)>$ 굽기 $(77.1 \%)>$ 삶기 $(54.0 \%)$ 순으로 엽산 잔존율이 낮아진 반면 표고버섯은 삶기 $(75.6 \%)>$ 튀기기 $(73.1 \%)>$ 볶기 $(72.0 \%)>$ 굽기(60.3\%)순으로 삶기에서 가장 높은 잔존율을 나타내어 버섯의 종류에 따라 조리방법에 따른 엽산 잔존율 영향 정도가 다르게 나타나는 것을 확인 할 수 있었다. Stea 등(31)의 연구에서도 브로콜리를 5 분 동안 찌는 조리법에서 약 $140 \%$ 로 엽산 잔존율이 높아졌으 나 감자를 삶았을 경우에는 약 $60 \%$ 의 잔존율로 낮아짐을 보고하여 같은 조리법이라도 시료에 따라 엽산의 잔존율이 달라질 수 있음을 보여주었다. 이러한 엽산의 잔존율의 차 이는 시료가 가지는 매트릭스의 영향으로 보여지며 이에 대해서는 보다 세부적인 연구가 필요할 것으로 여겨진다. 


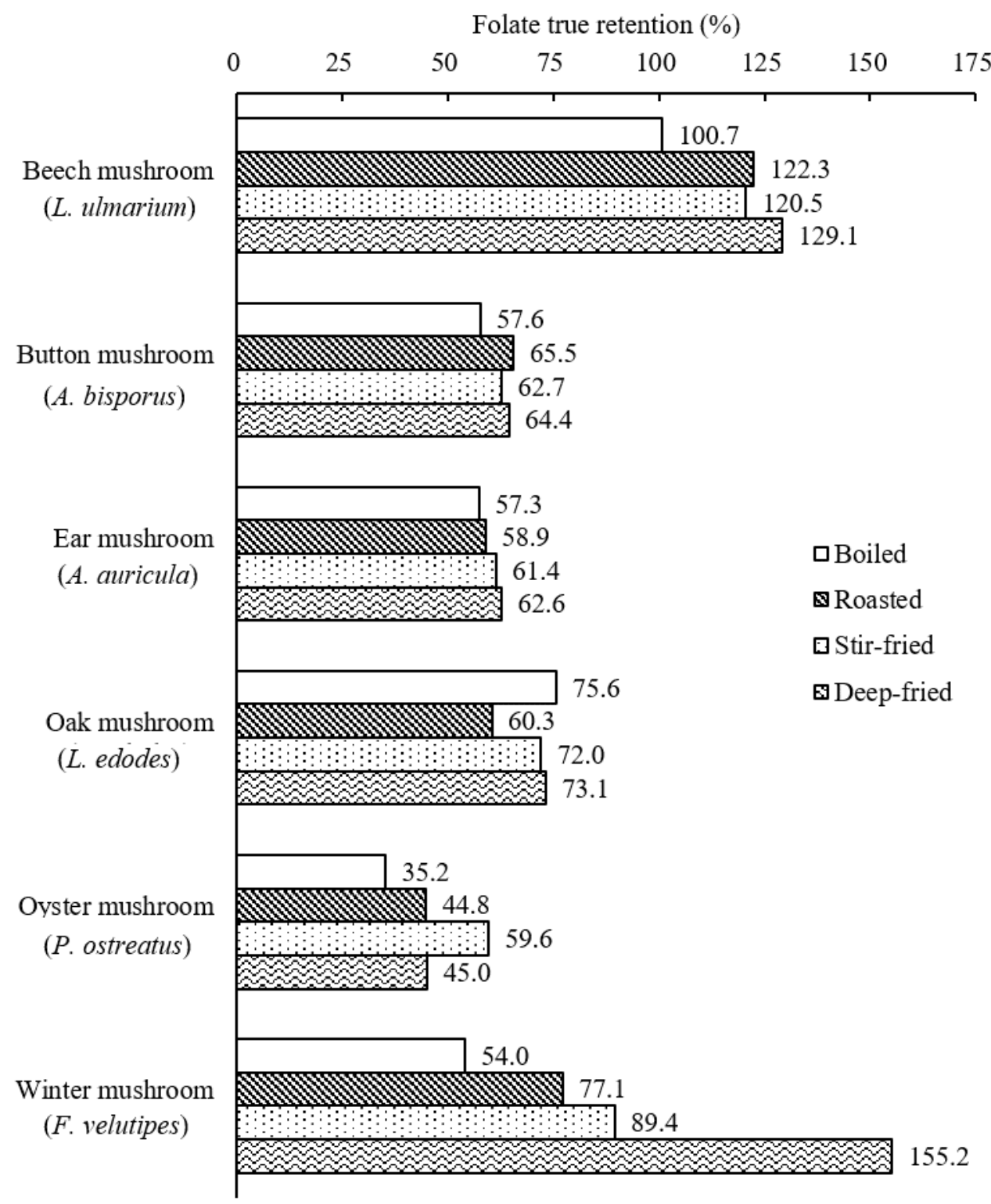

Fig. 3. True retention of folate in six mushrooms affected by different cooking methods.

True retention $(\%)=100 \times(\mathrm{Nc} \times \mathrm{Gc})(\mathrm{Nr} \times \mathrm{Gr})$.

$\mathrm{Nc}=$ nutrient content/gram of cooked food; $\mathrm{Gc}=$ gram of cooked food; $\mathrm{Nr}=$ nutrient content/gram of raw food; $\mathrm{Gr}=$ gram of raw food.

\section{요 약}

엽산은 체내에서 아미노산과 핵산의 합성에 필수적인 성분이며, 세포 분열과 성장에도 중요한 역할을 담당하며 유아기, 성장기, 임신기 및 수유기에 높게 요구되는 수용성 비타민이다. 버섯류는 다양한 영양 및 생리활성 성분의 존 재가 알려지면서 국내 식단에서 차지하는 비중이 점차 높아 지고 있으나 실제로 섭취하게 되는 조리된 버섯류의 엽산 성분에 관한 데이터베이스는 거의 전무한 실정이다. 본 연
구는 4가지 표준조리법(삶기, 굽기, 볶기, 튀기기)에 따른 6종 버섯(백만송이버섯, 양송이버섯, 목이버섯, 표고버섯, 느타리버섯, 팽이버섯)의 엽산 함량 변화를 분석하고 조리 전 후의 중량 변화를 고려한 가공계수를 산출하였으며 이를 적용한 엽산 잔존율을 평가하였다. 또한, 분석 결과의 국가 영양성분 데이터베이스로의 활용을 위하여 엽산 분석에 사용된 trienzyme extraction- $L$ casei 분석법을 검증하고 내 외부 분석품질관리를 수행하여 분석 결과의 신뢰도를 확보 하였다. 생버섯 6종의 엽산 함량은 버섯의 종류에 따라 
6.04-64.82 $\mathrm{\mu g} / 100 \mathrm{~g}$ 의 범위를 나타내었으며(느타리버섯 > 팽이버섯 > 표고버섯 > 양송이버섯 > 백만송이버섯 > 목이 버섯) 이는 조리법의 종류에 따라 다양하게 변화되었다. 목이, 표고, 및 느타리버섯은 네 가지 모든 조리법에서 엽산 함량이 각각 22-48, 2-31, 17-56\%로 감소된 반면, 백만송이 버섯은 모든 조리법에서 $17-90 \%$ 증가되었다. 한편, 양송이 버섯과 팽이버섯의 경우, 삶기에서는 생버섯에 비하여 엽 산 함량이 각각 $16 \%$ 와 $34 \%$ 감소한 반면, 튀기기에서는 각각 $24 \%$ 와 $465 \%$ 의 증가를 나타냈다. 조리 전후의 버섯의 중량 차이는 조리수를 이용한 삶기에서 가장 적었으며 고온 에서 조리되는 튀기기에서 가장 높게 나타났다. 이러한 조 리법에 따른 무게 변화를 고려한 가공계수를 고려하여 엽산 잔존율을 계산한 결과, 백만송이버섯을 제외한 5 종 버섯에 서는 대부분의 조리법에서 $100 \%$ 이하의 잔존율을 보였으 며, 전체적으로 삶는 조리법에서 엽산 잔존율 감소가 크게 나타났으며 튀기는 조리법에서는 비교적 잔존율이 높게 유지되었다. Trienzyme extraction- $L$ casei 분석법을 검증한 결과 우수한 정확성과(회수율 $100.4 \%$ ) 정밀성(CV 3\% 이 하)을 확인할 수 있었다. 또한, 본 연구가 진행되는 전 기간 동안 품질관리시료를 분석한 결과가 $\mathrm{QC}$ chart 관리수준 범위(172.58-188.20 $\mathrm{\mu g} / 100 \mathrm{~g})$ 이내에 들어가 모든 분석이 관리하에 진행되었음이 확인되었다. FAPAS PT 시험에서 trienzyme extraction- $L$. casei 분석법이 z-score=-0.5를 얻어 분석 숙련도의 우수성도 확인할 수 있었다. 이러한 분석법 검증 및 품질관리 결과는 본 연구에서 생산된 생버섯 및 조리 버섯의 엽산 분석 데이터의 신뢰도가 우수함을 보여주 는 것으로써 이는 국가식품 데이터베이스 구축을 위해 활용 될 수 있을 것으로 판단된다.

\section{감사의 글}

본 연구는 2016년도 식품의약품안전처의 연구개발비 (15162MFDS039)로 수행되었으며 이에 감사드립니다.

\section{References}

1. Zarkin GA, Dean N, Mauskopf JA, Williams R (1993) Potential health benefits of nutrition label changes. Am J Public Health, 83, 717-724

2. Graham DJ, Laska MN (2012) Nutrition label use partially mediates the relationship between attitude toward healthy eating and overall dietary quality among college students. J Acad Nutr Diet, 112, 414-418

3. Arcot J, Shrestha A (2005) Folate: methods of analysis. Trends Food Sci Technol, 16, 253-266
4. Ji HJ, Kim S, Yon M, Hyun T (2009) Folate content of fast foods and processed foods. Korean J Nutr, 42, 397-405

5. Chang N, Kang M, Paik HY, Kim IH, Cho YW, Park SC, Shin YW (1993) Serum folate and iron levels of pregnant, lactating, and non-pregnant, non-lactating women. Korean J Nutr, 26, 67-75

6. Kang M, Chang N (1993) Effect of dietary folate intakes on serum folate levels of pregnant and lactating women. Korean J Nutr, 26, 433-442

7. Lee $J$ (2007) Effect of UV-B irradiation on vitamin $D_{2}$ contents, color value and flavor pattern in Pleurotus ostreatus. Korean J Food Cook Sci, 23, 99-106

8. Cho YJ, Kim KH, Yook HS (2015) Protective effect of edible mushrooms (Pleurotus ostreatus, Flammulina velutipes, Lentinula edodes) according to different cooking methods on DNA damage of Jurkat cell line. Korean J Food Nutr, 28, 34-39

9. Park MH, Oh KT, Lee BW (1998) Anti-cancer activity of Lentinus edoeds and Pleurotus astreatus. Korean J Food Sci Technol, 30, 702-708

10. Ham SS, Oh SW, Kim YK, Shin KS, Chang HY, Chung GH (2003) Antioxidant and genotoxic inhibition activity of ethanol extract from the Inonotus obliquus. J Korean Soc Food Sci Nutr, 30, 1071-1075

11. Kim HK, Han HS, Lee GD, Kim KH (2005) Physiological activities of fresh Pleurotus eryngii extracts. J Korean Soc Food Sci Nutr, 34, 439-445

12. Xu XM, Jun JY, Jeong IH (2007) A study on the antioxidant activity of Hae-Songi mushroom (Hypsizigus marmoreus) hot water extracts. J Korean Soc Food Sci Nutr, 36, 1351-1357

13. Pellegrini N, Chiavaro E, Gardana C, Mazzeo T, Contino D, Gallo M, Riso P, Fogliano V, Porrini, M (2010) Effect of different cooking methods on color, phytochemical concentration, and antioxidant capacity of raw and frozen Brassica vegetables. J Agric Food Chem, 58, 4310-4321

14. Burg P, Fraile P (1995) Vitamin C destruction during the cooking of a potato dish. LWT-Food Sci Technol, 28, 506-514

15. Roy MK, Juneja LR, Isobe S, Tsushida T (2009) Steam processed broccoli (Brassica oleracea) has higher antioxidant activity in chemical and cellular assay systems. Food Chem, 114, 263-269

16. Hwang ES, Kim GH (2011) Different cooking methods for Korean cabbage and their effect on antioxidant activity and carotenoid and tocopherol contents. Korean J Food 
Cookery Sci, 27, 713-721

17. Jeong $\mathrm{CH}$, Shim KH (2004) Quality characteristics of sponge cakes with addition of Pleurotus eryngii mushroom powders. J Korean Soc Food Sci Nutr, 33, 716-722

18. Kim HR, Hong JS, Choi JS, Han GJ, Kim TY, Kim SB, Chun HK (2005) Properties of wet noodle changed by the addition of Sanghwang mushroom (Phellinus linteus) powder and extract. Korean J Food Sci Technol, 37, 579-583

19. Lee JS, Jeong SS (2009) Quality characteristics of cookies prepared with button mushroom (Agaricus bisporous) powder. Korean J Food Cookery Sci, 25, 98-105

20. Chun J, Martin JA, Chen L, Lee J, Ye L, Eitenmiller RR (2006) A differential assay of folic acid and total folate in foods containing enriched cereal-grain products to calculate $\mu \mathrm{g}$ dietary folate equivalents ( $\mu \mathrm{g} \mathrm{DFE}$ ). J Food Compos Anal, 19, 182-187

21. AOAC (2002) AOAC Guidelines for single laboratory validation of chemical methods for dietary supplements and botanicals. AOAC International, Gaithersburg, MD, USA, p 12-27

22. Kim HG, Lee KJ, Kim SM, Chung HJ (2010) Nutritional retention factor of $1+$ quality grade Hanwoo beef using different cooking methods. Korean J Food Sci Anim Resour, 30, 1024-1030

23. Puwastien $P$, Pinprapai N, Judprasong $K$, Tamura $T$ (2005) International inter-laboratory analyses of food folate. J Food Compos Anal, 18, 387-397
24. World Health Organization (2013) WHO expert consultation on rabies: second report (No. 982). World Health Organization, Geneva, Switzerland, 1-9

25. Noh H, Nicolas G, Paik HY, Kim J, Slimani N (2017) Improving standardization of national nutrient databases for use in international settings: A Korean proof of concept. J Food Compos Anal, 64, 55-63

26. Park HO, Oh HS, Yoon $S$ (2001) The changes of Vit. $D_{2}$ and Vit. $\mathrm{B}_{2}$ contents according to ultraviolet rays and cooking methods of mushrooms. Korean J Dietary Culture, 16, 463-469

27. Kim BM, Kim SM, Oh JY, Cho YS, Kim SN, Choi Y (2014) Total folate contents of 15 edible plants consumed in Korea using trienzyme extraction method. J Korean Soc Food Sci Nutr, 43, 1796-1800

28. Min HS (1998) Changes of folate content in spinach by cooking and storage-the comparisons of thermal destruction and loss of folate into cooking water by blanching time of spinach. J Korean Soc Food Sci Nutr, 27, 286-290

29. Kim JS, Han JS, Lee JS (1995) A study for the mechanical and sensory characteristics of mushrooms by various cooking methods. Korean J Soc Food Sci, 11, 44-50

30. Haytowitz DB (2006) Nutrient content and nutrient retention of selected mushrooms. Paper presented at 2006 IFT Annual Meeting, June 24-28, Orlando, FL, USA

31. Stea TH, Johansson M, Jägerstad M, Frølich W (2006) Retention of folates in cooked, stored and reheated peas, broccoli and potatoes for use in modern large-scale service systems. Food Chem, 101, 1095-1107 